\title{
Residual Effects and Energy Cost of Gliding Arc Discharge Treatment on the Inactivation of E. coli in Water
}

Hyoung-Sup Kim $^{\text {a)}}$, D.H. Lee ${ }^{\text {b) }}$, Alexander Fridman ${ }^{\text {a)}}$, Young I. Cho ${ }^{\text {a) }}$

a) Department of Mechanical Engineering and Mechanics, Drexel University, Philadelphia, Pennsylvania, USA

b) Department of Mechanical Design Engineering, Chonbuk National University, Jeonju, Republic of Korea

\begin{abstract}
The present study investigated the residual effect of gliding arc discharge (GAD) treatment on the inactivation of bacteria in a large volume of water (i.e., 20 L). Pure water and air were introduced to GAD separately, and then both the gas and water treated by plasma were sent to bacteria-containing water. Water contaminated by Escherichia coli (E. coli) was first treated by GAD for 10, 13 and 16, and 25 min and then stored for the next $4 \mathrm{~h}$, during which time the E. coli concentration and $\mathrm{pH}$ were measured. In general, GAD produced the strong anti-microbial properties, a phenomenon which increased with plasma treatment time. More specifically, E. coli was partially inactivated (i.e., approximately $2.7-\log$ reduction) with 16-min plasma treatment. However, E. coli was almost completely inactivated (over 99.9 \% with 5-log reduction) during the subsequent 4-h storage period, a phenomenon that was attributed to the residual effect of the plasma treatment. The optimum plasma energy cost of the GAD treatment to inactivate $\mathrm{E}$. coli in $20-\mathrm{L}$ water in the present study was found to be approximately $0.57 \mathrm{~kJ} / \mathrm{L}$ per 1-log reduction.
\end{abstract}


Key Words: Gliding arc discharge, E. coli, Bacterial inactivation, Residual effect, Energy cost of plasma treatment, Water treatment Corresponding Author: Young I. Cho, Department of Mechanical Engineering and Mechanics, Drexel University, Philadelphia, Pennsylvania, USA.

Tel.: +1 215895 2425, fax: +1 215895 1478, E-mail address: choyi@ drexel.edu

$\begin{array}{llll}\text { Nomenclature } & & \\ \mathrm{E}_{\mathrm{d}} & \text { deposited plasma energy } & k(\mathrm{~T}) & \text { rate constant } \\ U(\mathrm{t}) & \text { voltage profile } & \mathrm{E}_{\mathrm{a}} & \text { activation energy } \\ l(\mathrm{t}) & \text { current profile } & \mathrm{R} & \text { gas constant } \\ \mathrm{f} & \text { frequency } & \mathrm{A}, \mathrm{n} & \text { coefficients in rate constants } \\ \mathrm{T} & \text { pulse period } & \mathrm{T} & \text { plasma temperature }\end{array}$

\section{Introduction}

Plasma treatment is a promising, non-chemical method for inactivation of microorganisms in water [1-4]. The inactivation effect has been attributed to the ability of plasma discharges to generate active plasma species, i.e., $\mathrm{OH}, \mathrm{O}, \mathrm{O}_{3}, \mathrm{H}_{2} \mathrm{O}_{2}, \mathrm{NO}_{\mathrm{x}}, \mathrm{UV}$ and electric fields [5-9]. Each of these plasma species may play a role in the inactivation of microorganisms. However, most of the active species have very short half-lives on the order of $\mu$ s or less [10-13]. The exceptions to these are $\mathrm{H}_{2} \mathrm{O}_{2}$ and ozone, which have relatively long half-lives, and as a result, may be especially useful in the treatment of larger volumes of contaminated water [14, 15]. Ozone is often produced in air using a compressor equipped with dryer and cooler and then mixed with water in a two-step process [16-18]. On the other hand, $\mathrm{H}_{2} \mathrm{O}_{2}$ can be produced directly in water 
through the dissociation of water molecules by plasma discharges [9, 19, 20]. Furthermore, hydrogen peroxide concentration can persist in water for relatively long durations, i.e., over a 10-min timescale [21]. The energy yield of $80 \mathrm{~g} / \mathrm{kWh}$ for $\mathrm{H}_{2} \mathrm{O}_{2}$ formation was reported with a two-dimensional gliding arc discharge (GAD) with oxygen and argon gases in divergentchannel electrodes [19], whereas three-dimensional GAD used in the present study gave an energy yield of $7.3 \mathrm{~g} / \mathrm{kWh}$ for $\mathrm{H}_{2} \mathrm{O}_{2}$ formation with air [21].

The GAD is able to generate a large amount of active plasma species because of its unique plasma properties and the gas flow inside the GAD generator. The GAD can be defined as an auto-oscillating periodic discharge between at least two diverging or non-diverging electrodes propelled by a gaseous flow [9], resulting in a sufficiently high degree of non-equilibrium to sustain a selective chemical process [22]. The arc discharge first ignites as thermal plasma at the locus of the smallest gap between the two electrodes. Then, the arc is forced to move downstream by a stream of gas and is convectively cooled by a stream of room-temperature gas, becoming a non-equilibrium discharge during the space-time evolution. The stream of gas in the GAD used in the present study flows through a cylindrical three-dimensional geometry, creating a reverse vortex flow (i.e., tornado) [9, 22-28].

The vortex flow regime provides excellent thermal insulation of active species from the cylindrical wall, reducing energy loss to the surroundings, thereby increasing its energy efficiency. Another benefit of the GAD in vortex flow is that the residence time of gas to be treated by plasma is relatively long, a desirable phenomenon for various chemical reactions. Thus, the rotating GAD can provide increased specific power input, reduced energy cost, and uniform treatment of gas $[23,27]$. 
The long residence time of treatment and the high concentration of $\mathrm{H}_{2} \mathrm{O}_{2}$ in water generated by the GAD are essential to bacterial inactivation [29]. Previously, it was reported that the concentration of $\mathrm{H}_{2} \mathrm{O}_{2}$ in water was found to be over $30 \mathrm{ppm}$ as determined using a peroxide test strip in the case of $120 \mathrm{~mL} / \mathrm{min}$ of water injection to GAD generator [21].

In our previous study [30], a small amount of water was injected to the plasma jet coming out of the exit of the GAD generator so that water molecules could be dissociated, resulting in the recombination of hydroxyl radicals, forming $\mathrm{H}_{2} \mathrm{O}_{2}$ [31], and at the same time, reducing the $\mathrm{pH}$ of water $[4,30,32]$. The combined effects of $\mathrm{H}_{2} \mathrm{O}_{2}$ and low-pH water on the inactivation of bacteria in a large volume of water (i.e., $20 \mathrm{~L}$ ) were reported to be beneficial, where a 2-log reduction in counts of colony forming units (cfu) for E. coli with GAD treatment of 25 min was demonstrated with a total energy cost of $8.1 \mathrm{~kJ} / \mathrm{L}$ per 1-log reduction $[30,33]$. Recently, the total energy cost was further reduced to $6.5 \mathrm{~kJ} / \mathrm{L}$ per $1-\log$ reduction, i.e., an improvement by approximately $20 \%$, where microbubble generators were used to improve the mixing between plasma-treated water and gas [33].

When the plasma-treated water is kept in a closed reservoir, the low-pH in water can be maintained for an extended period of time. Hence, it is hypothesized that the anti-microbial power of plasma-treated water $[8,24]$ might also be maintained over the extended period of time after the completion of the plasma treatment.

In consideration of this hypothesis, the objective of the study was to investigate the residual effects of GAD treatment on the inactivation of bacteria for a large volume of water. In addition, the present study also investigated the plasma energy cost of the GAD treatments of water contaminated with E. coli, including the residual benefit of anti-microbial properties of plasmatreated water. 


\section{Experimental Methods}

The experimental setup used in the present study is illustrated in Fig. 1. The test setup consisted of three major parts: the first part comprised of two identical GAD generators, each driven by its own power supply; the second part was made of air and water-transport systems to provide controlled flows of air and water to the GAD generators; and the third part was made of a reservoir tank with two microbubble generators to store bacteria-contaminated water and to receive plasma-treated air and distilled water. The basic approach in the study was to have both air and distilled water pass through the GAD generator first and, then, to introduce plasmatreated air and water to a large volume of contaminated water at the reservoir (see Fig. 1). In order to provide a fixed airflow of $3.8 \mathrm{scfm}$ to each of the two GAD generators, an air compressor together with a valve and a pressure regulator was used. The compressed air was also sent to the top of distilled water reservoir, as shown in Fig. 1, so that water could be pushed out through an exit located at the bottom of the reservoir at the uniform flow rate of 120 $\mathrm{mL} / \mathrm{min}$, which was monitored by a flow meter (FL-3839G, Omega)

Since more detailed descriptions of GAD generator have been given elsewhere [21, 30], it will be described only briefly here. Each set of two stainless steel electrodes separated by a gap of $2.5 \mathrm{~mm}$ was connected to a high-voltage power supply, which delivered $200 \mathrm{~W}$. Since two GAD generators were used in the study, and each GAD generator was powered by its own power supply, the total power consumption was $400 \mathrm{~W}$ for both plasma discharges. Compressed air was tangentially introduced to the gap space between two circular electrodes through six small nozzles in the GAD generator, resulting in a reverse vortex flow. Water was also injected tangentially through another set of six small nozzles to the plasma arc jet exiting from the center hole in the circular electrodes. 
Fig. 2 shows the schematic circuit diagram of the power supply used in this study, which is designed to produce alternating high voltage (HV) and current at a frequency of $33.3 \mathrm{kHz}(\mathrm{B} \& \mathrm{~N}$ Inc., South Korea). The power supply mainly consisted of four components; voltage rectifier with diode bridges, capacitors, high voltage transformer, and a transistor.

Fig. 3 shows voltage and current profiles produced by the AC HV power supply, which were measured and recorded by a digital phosphor oscilloscope (TDS3014C, Tektronix). For the measurement of the current, a magnetic core current probe was utilized (CM-10-L, Ion Physics Corporation, Fremont, $\mathrm{NH}$ ), whereas the voltage was measured using a high voltage probe (P6015A, High Voltage Probe 1000X 75MHz, Tektronix). Peak-to-peak voltage (U) and current (I) were determined to be $5.6 \mathrm{kV}$ (based on settings of $1.0 \mathrm{~V}$ per division $\mathrm{x} 1000$ for the voltage probe) and $0.75 \mathrm{~A}$ (based on settings of $50 \mathrm{mV}$ per division $\mathrm{x} 10 \mathrm{~A} / \mathrm{V}$ for the current probe). The frequency (f) of $\mathrm{HV}$ pulses was $33.3 \mathrm{kHz}$, a value that was determined from pulse period $(\mathrm{T})$ of $30 \mu$ s measured with the oscilloscope.

By integrating the voltage and current profiles over 1 pulse cycle, the deposited energy $\left(E_{d}\right)$ into the GAD per 1 pulse cycle and per $1 \mathrm{~s}$ can be calculated, respectively, as:

$$
\begin{aligned}
& \mathrm{E}_{\mathrm{d}} / \text { pulse }=\int_{i=0}^{t=2 \pi} U(t) I(t) d t \\
& \mathrm{E}_{\mathrm{d}} / \text { second }=\int_{i=0}^{t=2 \pi} U(t) I(t) d t \mathrm{x} \mathrm{f}
\end{aligned}
$$

The values of $E_{d} /$ pulse and $E_{d} /$ second were approximately $8.92 \times 10^{-4} \mathrm{~J} /$ pulse and $29.71 \mathrm{~J} / \mathrm{s}$. These were used to calculate the plasma energy cost and D-value, which are given in the Result section.

The contaminated water reservoir was cleaned after each test with both sulfuric acid and tap water repeatedly and then dried in a fume hood. Then, the water reservoir was filled with $20 \mathrm{~L}$ 
of distilled water to prepare for the next test, and the flexible tube from the GAD generator was re-connected to the reservoir.

The flow rate of water to each GAD generator was $120 \mathrm{~mL} / \mathrm{min}$ at a uniform air flow rate of $3.8 \mathrm{scfm}$, an optimal condition for the present GAD generator [21, 30]. The concentrations of $\mathrm{H}_{2} \mathrm{O}_{2}$ in the plasma-treated water obtained at various test conditions of different flow rates of air and water through GAD generator were measured in the form of color changes with peroxide test strips (EMD Chemicals, Germany). Due to the limitation in collecting a sample of $\mathrm{H}_{2} \mathrm{O}_{2}$ in gas phase [21, 34], the concentration of $\mathrm{H}_{2} \mathrm{O}_{2}$ in water samples only was measured (see Fig. 4). The $\mathrm{pH}$ level in plasma-treated water was measured with a $\mathrm{pH}$ meter (HI 9125N, HANNA Instruments, Smithfield, RI). Prior to each experiment, the $\mathrm{pH}$ meter was calibrated at three points (i.e., $\mathrm{pH}: 4,7$, and 10) using standard-pH solutions provided by the manufacturer, and each sample was measured 5 times, from which the mean value and standard deviation were obtained. The temperature of water in the reservoir was also measured using a thermometer (52 II, Fluke) whenever pH measurement was done.

Escherichia coli (E. coli) was used for the present bacterial inactivation experiments. Cultures of E. coli were grown for $18 \mathrm{~h}$ at $37^{\circ} \mathrm{C}$ in an incubator and diluted using the most probable number method [35], yielding a range of concentrations between $10^{5}-10^{6}$ colony forming units per milliliter $(\mathrm{cfu} / \mathrm{mL})$ as initial test conditions. The cfu measurements in all water samples were conducted using an aerobic heterotrophic plate count (HPC) method by the serial dilutions of samples [36, 37]. For bacterial inactivation tests, cultures of E. coli were added to the reservoir filled with distilled water of $20 \mathrm{~L}$. Immediately after adding E. coli to water, the water reservoir was continuously stirred using an electrical stirrer (Eurostar/IKA, Staufen, 
Germany) at $650 \mathrm{rpm}$ to disperse E. coli uniformly in the reservoir. After stirring water for 5 min, 50-mL samples were collected in sterile tubes for cfu counts.

Prior to plasma inactivation tests, a control test (see Fig. 5) was performed with an initial bacterial count of $10^{5} \mathrm{cfu} / \mathrm{mL}$ in the reservoir holding $20 \mathrm{~L}$ of contaminated distilled water, where an additional $2.8 \mathrm{~L}$ of distilled water was introduced through the GAD generator at a flow rate of $2 \times 120 \mathrm{~mL} / \mathrm{min}$ for $16 \mathrm{~min}$ as per procedures but with the plasma power turned off. The water was then kept at the reservoir for the next $4 \mathrm{~h}$, during which time the cfu numbers in water was determined.

In cases with plasma treatment, the initial concentration of E. coli in the reservoir varied from $10^{5}$ to $10^{6} \mathrm{cfu} / \mathrm{mL}$. Plasma treatments were conducted for 10,13,16 and $25 \mathrm{~min}$, during which both plasma-treated water and air were continuously delivered to the reservoir. The initial volume of the contaminated water in the reservoir was $20 \mathrm{~L}$ in all tests. For the cases of 10, 13, 16 and 25 -min treatments, approximately 2.4, 3.1, 3.8 and $6 \mathrm{~L}$ of plasma-treated water, respectively, were added to the reservoir during the treatment.

Two water samples of $50 \mathrm{~mL}$ each (including at $\mathrm{t}=0$, i.e., before treatment) were collected for cfu and $\mathrm{pH}$ measurements during the plasma treatment period, and 8 additional samples of $50 \mathrm{~mL}$ each were also collected from the contaminated water reservoir every $30 \mathrm{~min}$ (at $\mathrm{t}=30$, 60, 90, 120, 150, 180, 210 and $240 \mathrm{~min}$ ) during the storage period (see Fig. 6A - 6D). 1-mL water sample for cfu measurement at each time period was collected using a sterile pipette from 50-mL water sample, which was continuously stirred with a vortex mixer (Fisher Scientific: Genie 2). Each 1-mL sample water was spread on Brain Heart Infusion Agar plate (Fisher Scientific) inside a clean bench within $5 \mathrm{~min}$ after collecting the $50-\mathrm{mL}$ water sample from the reservoir. All agar plates containing water samples were dried for $30 \mathrm{~min}$ at room temperature 
inside the clean bench and incubated for $18 \mathrm{~h}$ at $37^{\circ} \mathrm{C}[38,39]$. The number of colony forming units was determined using a colony counter (Digital Colony Counter/HYC-560, Korea), which has a measurement error (i.e., sensitivity) of $7.9 \%$ in the measurement range for $10^{2} \mathrm{cfu}$ or greater. Prior to performing cfu counts of E. coli on agar plates after incubating, the HPC images were recorded with a digital camera. The above measurements of the cfu of E. coli were repeated three times for each water sample, from which both the mean value of cfu/mL and the standard deviation were obtained and shown in Figs. 5 and 6.

\section{Results}

Fig. 4 shows the results of $\mathrm{H}_{2} \mathrm{O}_{2}$ concentrations in water collected from the connecting line between GAD generator and water reservoir tank at 3 different air flow rates and 5 different water flow rates. As the water flow rate varied from 140 to $20 \mathrm{~mL} / \mathrm{min}$, the concentration of $\mathrm{H}_{2} \mathrm{O}_{2}$ in the plasma-treated water increased from 20 to $100 \mathrm{ppm}$. The maximum concentration of $\mathrm{H}_{2} \mathrm{O}_{2}$ of $100 \mathrm{ppm}$ was obtained at the lowest water flow rate of $20 \mathrm{~mL} / \mathrm{min}$. In the present study, a uniform water flow rate of $120 \mathrm{~mL} / \mathrm{min}$ was used for all bacterial inactivation tests because the large water flow rate provided a minimal temperature increase in plasma-treated water $[21,30]$.

Fig. 5 shows photographic HPC images for the control case, where the control sample (i.e., without plasma treatment) maintained its initial cfu number of $10^{5}$ per $\mathrm{mL}$ during 16 -min period of the sham treatment under identical test conditions (i.e., with the same water and air flow rates through GAD generator), and the cfu/mL number was maintained within $\pm 15 \%$ during the next 4-h storage period. Significant levels of cultured E. coli were observed in the HPC images in water collected from the reservoir in the control test when the water was not treated with plasma. 
Fig. 6A-6C show photographic HPC images obtained in the cases of 10, 13, and 16-min plasma treatments with an initial E. coli concentration of $10^{5} \mathrm{cfu} / \mathrm{mL}$. Fig. $6 \mathrm{D}$ shows the corresponding images for the case of 25-min plasma treatment with an initial E. coli concentration of $10^{6} \mathrm{cfu} / \mathrm{mL}$.

The energy cost for the present plasma treatment was determined using the values of the deposited energy $\left(E_{d}\right)$ obtained from the integration of the voltage and current profiles as:

$$
\text { Energy cost/L }(\mathrm{kJ} / \mathrm{L})=2 \times\left(\mathrm{E}_{\mathrm{d}} / \mathrm{s}\right) \times \text { treatment time }(\min ) \times 60 \mathrm{~s} / 20 \mathrm{~L}
$$

where the constant 2 is for two GAD generators used in the present study. For the cases of 10,13,16, and 25-min plasma treatment, the plasma energy costs were determined as $1.78,2.31,2.85$, and $4.56 \mathrm{~kJ} / \mathrm{L}$, respectively.

The cfu data for the cases with plasma treatments were consistently reduced with increasing plasma treatment time (i.e., plasma intensity). In addition, the $\mathrm{pH}$ significantly reduced with the plasma treatment and remained at a reduced level during the subsequent storage period.

Fig. 6A also shows the cfu counts for the case of 10-min plasma treatment, followed by 4-h storage. The value of cfu/mL decreased to $5130 \pm 110$ (i.e., 1.5-log reduction) at the end of the plasma treatment, which was further reduced to $35 \pm 14 \mathrm{cfu} / \mathrm{mL}$ (i.e., $2.1-\log$ reduction) at the end of the 4-h storage period, resulting in a total 3.6-log reduction.

Fig. 6B and 6C show the cfu results for the cases of 13 and 16-min plasma treatments, respectively. The results in Fig. $6 \mathrm{~B}$ show $2-\log$ reduction in $\mathrm{cfu} / \mathrm{mL}$ at the end of the plasma treatment with an additional 2-log reduction during the subsequent storage period, resulting in a total 4-log reduction. The results in Fig. 6C show nearly 2.7-log reduction at the end of the 16- 
min plasma treatment with an additional 2.3-log reduction during the subsequent storage period, resulting in a total 5-log reduction at the plasma energy cost of $2.85 \mathrm{~kJ} / \mathrm{L}$.

Fig. 6D shows the cfu counts for the case of 25-min plasma treatments with an initial condition of $10^{6} \mathrm{cfu} / \mathrm{mL}$. At the end of the plasma treatment, there was 3.5-log reduction followed by an additional 2.5-log reduction after 2-h storage, resulting in a total 6-log reduction, a better reduction performance than the case of the 16-min treatment, but at a significantly increased plasma energy cost of $4.56 \mathrm{~kJ} / \mathrm{L}$.

Using the data on the log-reduction, the plasma energy cost including the residual effects in plasma-treated water becomes $0.50,0.58,0.57$ and $0.74 \mathrm{~kJ} / \mathrm{L} / 1-\log$ reduction for the cases of 10 , 13, 16, and 25-min plasma treatment, respectively. This residual effect of the anti-microbial properties significantly improves the plasma energy cost. The best plasma energy cost to inactivate E. coli in $20-\mathrm{L}$ water in the present study was found to be approximately $0.57 \mathrm{~kJ} / \mathrm{L}$ per1-log reduction in $\mathrm{cfu} / \mathrm{mL}$ of E. coli corresponding to the 16-plasma treatment. Accordingly, the case with the 16-plasma treatment was considered the best performance in terms of plasma energy cost and bacterial inactivation capability among the tests conducted in the present study.

Fig. 7 shows the variations in E. coli concentrations for all cases in the present study, including the control case (i.e., no treatment), whereas Fig. 8 provides the variations in $\mathrm{pH}$ during the plasma treatment and subsequent storage periods. The temperature increase in the plasma-treated water was found to be less than $6^{\circ} \mathrm{C} \pm 0.05 \%$ after 25 -min plasma treatment. However, since the plasma-treated water was introduced to a large volume of water in the reservoir, the temperature rise in the contaminated water in the reservoir was negligible in this study. 
Comparing the bacterial inactivation results with the $\mathrm{pH}$ variations in all plasma-treated cases, the reductions in $\mathrm{pH}$ and E. coli concentration followed similar trends. Pooling together all of the test data across 5 arms of this study $(10,13,16,25$ min of plasma treatment and no treatment control), reflecting a range of treatment durations and storage times, a moderately strong correlation was observed between $\mathrm{pH}$ and E. coli concentration using Student's t-test $(\mathrm{R}=0.52, \mathrm{p}=0.0004)$. For the plasma treatment cases with $10,13,16$ and 25 min, the mean $\mathrm{pH}$ values in the contaminated water in the reservoir decreased from the initial $\mathrm{pH}$ of $6.13 \pm 0.03$ to $3.95 \pm 0.03,3.83 \pm 0.01,3.68 \pm 0.02$ and $3.62 \pm 0.00$, respectively, at the end of the plasma treatment, which were maintained almost constant during the storage period. Since the reductions in E. coli concentration almost coincided with those in $\mathrm{pH}$ in the contaminated water, one can attribute the residual effects of the plasma treatment to the low-pH of water.

\section{Discussion}

Our previous studies reported that the GAD generator produced $\mathrm{H}_{2} \mathrm{O}_{2}$ in plasma-treated water $[21,30]$. Experimental results in the present study indicate that the $\mathrm{pH}$ in the treated water was reduced to as low as 3.62 in a large volume of water. The phenomenon of the formation of acidic water can be attributed to $\mathrm{H}_{3} \mathrm{O}^{+}$ions and nitric acid $\left(\mathrm{HNO}_{3}\right)$ generated from the plasma discharge [40].

When water is directly exposed to GAD, the following reactions occur with the dissociation of water molecules $[4,9,20,41]$ :

$$
\begin{aligned}
\mathrm{e}+\mathrm{H}_{2} \mathrm{O} & \rightarrow \mathrm{H}+\mathrm{OH}+\mathrm{e}^{-} \\
\mathrm{e}+\mathrm{H}_{2} \mathrm{O} & \rightarrow \mathrm{H}^{-}+\mathrm{OH} \\
\mathrm{M}^{+}+\mathrm{H}_{2} \mathrm{O} & \rightarrow \mathrm{H}_{2} \mathrm{O}^{+}+\mathrm{M} \\
\mathrm{H}_{2} \mathrm{O}^{+}+\mathrm{H}_{2} \mathrm{O} & \rightarrow \mathrm{H}_{3} \mathrm{O}^{+}+\mathrm{OH}
\end{aligned}
$$


Then, $\mathrm{H}_{2} \mathrm{O}_{2}$ is formed from the recombination of hydroxyl radicals $[9,19,20]$.

$$
\mathrm{OH}+\mathrm{OH}+\mathrm{M} \rightarrow \mathrm{H}_{2} \mathrm{O}_{2}+\mathrm{M}
$$

In the overall set of reactions, the concentration of $\mathrm{H}_{2} \mathrm{O}_{2}$ in water increases with plasma treatment $[21,40]$. A significant $\mathrm{pH}$ drop observed in the present study can be attributed to positive charges $\left(\mathrm{M}^{+}\right)$created in the plasma discharge that reach the water molecules and exchange charges with the water molecules, resulting in the creation of $\mathrm{H}_{3} \mathrm{O}^{+}$ions and $\mathrm{OH}$ radicals, both playing an important role in sterilization $[17,19,24,40]$ through Equations (4-4) to $(4-5)$.

When air is the carrier gas, nitrogen oxides can be formed from gas phase reactions of dissociated nitrogen and oxygen [9, 40-45]

$$
\begin{array}{r}
\mathrm{N}_{2}+\mathrm{e} \rightarrow 2 \mathrm{~N}+\mathrm{e}- \\
\mathrm{O}_{2}+\mathrm{e} \rightarrow 2 \mathrm{O}+\mathrm{e}- \\
\mathrm{N}+\mathrm{O}+\mathrm{M} \rightarrow \mathrm{NO}+\mathrm{M} \\
\mathrm{NO}+\mathrm{O}+\mathrm{M} \rightarrow \mathrm{NO}_{2}+\mathrm{M}
\end{array}
$$

The nitrogen dioxide $\left(\mathrm{NO}_{2}\right)$ affects the $\mathrm{pH}$ of the water through the formation of acids and ions. The reaction between $\mathrm{NO}_{2}$, see Equation (5-4), and hydroxyl radicals $\mathrm{OH}$, see Equations (4-1) to (4-4), can generate $\mathrm{HNO}_{3}$, which results in acidic water [40, 41, 43, 46].

$$
\mathrm{NO}_{2}+\mathrm{OH} \rightarrow \mathrm{HNO}_{3}
$$

All chemical reactions and the rate constants in the form of an Arrhenius equation, which depend on plasma temperature (T), are listed in Table 1 in the following format:

$$
k(\mathrm{~T})=\mathrm{A}(\mathrm{T} / 298 \mathrm{~K})^{\mathrm{n}} \exp \left(-\mathrm{E}_{\mathrm{a}} / \mathrm{RT}\right)
$$


where $\mathrm{E}_{\mathrm{a}}$ is the activation Energy, $\mathrm{R}$ is the gas constant, and $\mathrm{A}$ and $\mathrm{n}$ are coefficients.

Table 1 presents these chemical reactions grouped by the temperature range. The four chemical reactions are shown in the high-temperature plasma zone at $\mathrm{T}=2,000 \mathrm{~K}$ or above. The $\mathrm{OH}$ radicals shown in the reactions of (4-1) and (4-2) are normally associated with the dissociation of the water vapor, as high energy electrons (radiation) with $5.1 \mathrm{eV} / \mathrm{mol}$ necessary for $\mathrm{H}_{2} \mathrm{O}$ dissociation pass through the water, yielding hydrogen and hydroxyl radicals [9, 20]. The other reactions of (5-1) and (5-2) in the high-temperature plasma zone explain the vibrational excitation of $\mathrm{N}_{2}$ and $\mathrm{O}_{2}$ molecules by the high electron energies between 1 and $3 \mathrm{eV} / \mathrm{mol}[9,47]$. Distilled water was introduced to the above plasma arc jet in the present study (see Fig. 2), so that the vibrational excitation occurred first in the high-temperature zone, immediately followed by the dissociation of water molecules.

When the plasma jet and treated water exiting from the high-temperature plasma zone of GAD generator, both of them become cooled as they move in the connecting pipe to the reservoir. Subsequently, the excited species (ie., $\mathrm{OH}, \mathrm{N}$ and $\mathrm{O}$ radicals) are rapidly quenched and then recombined to $\mathrm{H}_{2} \mathrm{O}_{2}$ and $\mathrm{HNO}_{3}$ through the reactions from (4-3) to (4-5) and (5-3) to (5-5) in the low-temperature plasma zone $[9,48]$.

A number of studies on the antimicrobial effects of plasma have indicated $\mathrm{OH}$ and $\mathrm{NO}$ as the effective species [5-9]. The generation of these two reactive species depends on the humidity of air injected into the GAD [47, 49]. For example, the concentration of $\mathrm{OH}$ generated by the GAD can increase much higher than that of NO as the humidity of the carrier gas increases. The $\mathrm{OH}$ formed from the dissociation of water can lead to the formation of $\mathrm{H}_{2} \mathrm{O}_{2}$ due to the recombination of $\mathrm{OH}$ as explained above. Hence, when pure water is injected into the 
plasma jet exiting from the GAD, the concentration of $\mathrm{H}_{2} \mathrm{O}_{2}$ becomes much higher than that of nitric acid $\left(\mathrm{HNO}_{3}\right)$ formed from the reaction of $\mathrm{OH}$ and $\mathrm{NO}_{\mathrm{x}}$. [40, 47]

The plasma water treatment system in the present study increased $\mathrm{H}_{2} \mathrm{O}_{2}$ concentration in water and decreased $\mathrm{pH}$ to a low level of 3.6. These two effects are proposed as the main mechanism for E. coli inactivation by the plasma treatment. Note that $\mathrm{H}_{2} \mathrm{O}_{2}$ itself is not a strong oxidizer. Also, note that acidic water alone is not a strong oxidizer. However $\mathrm{H}_{2} \mathrm{O}_{2}$ in the presence of acidic water becomes a very strong oxidizer and an effective tool for the inactivation of microorganisms, making a direct impact on the outer membrane of microorganisms due to the peroxidation of a cell membrane $[1,8]$. In the present study, as the plasma-treated water was pumped to a large volume of bacteria-filled water, the optimal bacterial inactivation was achieved with 16-min treatment, resulting from the combined effect of the high concentration of $\mathrm{H}_{2} \mathrm{O}_{2}$ and low-pH level in water. In other words, the plasma treatment in the case of 25 -min treatment gave a slightly better performance in the bacterial inactivation than the case of 16-min treatment, but at a significantly increased energy cost. Further inactivation was obtained through the residual effect of the plasma treatment as manifested by reduced cfu values by letting the plasma-treated water sit for several hours.

There have been a number of studies on E. coli inactivation by other types of plasma such as corona, capillary and DBD discharges directly in water [9, 50-56]. D-value, which can be defined as the energy cost per $\mathrm{L}$ per 1-log reduction (i.e., $90 \%$ ), varied from 3.3 to $33.3 \mathrm{~kJ} / \mathrm{L}$ per 1-log reduction [52-54]. The D-value obtained with a 3-dimensional GAD in the present study in $20-\mathrm{L}$ water was $0.57 \mathrm{~kJ} / \mathrm{L}$ per $1-\log$ reduction for 16 -min treatment case, indicating that the present GAD method of bacterial inactivation showed at least 5.7 times more energyefficient than those systems reported in the literature $[9,50-56]$. 


\section{Conclusions}

The present study reports the efficacy of plasma water treatment with a 3-dimensional GAD on the inactivation of contaminated water. Plasma treatment decreased the $\mathrm{pH}$ of water to 3.62 as $\mathrm{GAD}$ produced $\mathrm{H}_{3} \mathrm{O}^{+}$ions and $\mathrm{HNO}_{3}$. The efficacy of active plasma species such as $\mathrm{H}_{2} \mathrm{O}_{2}$ and low-pH on the inactivation of a large volume of water (i.e., $20 \mathrm{~L}$ ) has been demonstrated with plasma treatment of 10,13, 16 and $25 \mathrm{~min}$. Although the plasma treatment provided only partial inactivation at the end of the plasma treatment, remaining E. coli in water was further inactivated during the subsequent storage period by the residual effect of $\mathrm{H}_{2} \mathrm{O}_{2}$ and low-pH. The synergetic effect of $\mathrm{H}_{2} \mathrm{O}_{2}$ and low-pH in water is enhanced by a powerful residual effect during the post-treatment storage period, where no additional energy is consumed. Additional studies are needed to better understand the scale-up issue in the treatment of a significantly large volume of water.

\section{Acknowledgement}

Funding for this project (Contract Number: 11122-31) is provided by RPSEA through the "Ultra-Deepwater and Unconventional Natural Gas and Other Petroleum Resources" program authorized by the U.S. Energy Policy Act of 2005. RPSEA (www.rpsea.org) is a nonprofit corporation whose mission is to provide a stewardship role in ensuring the focused research, development and deployment of safe and environmentally responsible technology that can effectively deliver hydrocarbons from domestic resources to the citizens of the United States. RPSEA, operating as a consortium of premier U.S. energy research universities, industry, and independent research organizations, manages the program under a contract with the U.S. Department of Energy's National Energy Technology Laboratory. 


\section{References}

[1] Y. Yang, H. Kim, A. Starikovskiy, Y. Cho, and A. Fridman, "An underwater multichannel plasma array for water sterilization," Review of Scientific Instruments, vol. 82, p. 096103, 2011.

[2] G. Fridman, A. D. Brooks, M. Balasubramanian, A. Fridman, A. Gutsol, V. N. Vasilets, et al., "Comparison of Direct and Indirect Effects of Non-Thermal Atmospheric-Pressure Plasma on Bacteria," Plasma Processes and Polymers, vol. 4, pp. 370-375, 2007.

[3] N. De Geyter and R. Morent, "Nonthermal Plasma Sterilization of Living and Nonliving Surfaces," Annual Review of Biomedical Engineering, vol. 14, pp. 255-274, 2012.

[4] K. Oehmigen, M. Hähnel, R. Brandenburg, C. Wilke, K. D. Weltmann, and T. von Woedtke, "The role of acidification for antimicrobial activity of atmospheric pressure plasma in liquids," Plasma Processes and Polymers, vol. 7, pp. 250-257, 2010.

[5] A. Gutsol, N. Vaze, K. Arjunan, M. Gallagher, Y. Yang, J. Zhu, et al., "Plasma for air and water sterilization," Plasma Assisted Decontamination of Biological and Chemical Agents, pp. 21-39, 2008.

[6] B. Locke, M. Sato, P. Sunka, M. Hoffmann, and J. S. Chang, "Electrohydraulic discharge and nonthermal plasma for water treatment," Industrial \& Engineering Chemistry Research, vol. 45, pp. 882-905, 2006.

[7] D. Dobrynin, "Physical and chemical mechanisms of direct and controllable plasma interaction with living objects," 2011. Ph. D. Thesis, Drexel University, Philadelphia, PA. 
[8] D. Dobrynin, G. Fridman, G. Friedman, and A. Fridman, "Physical and biological mechanisms of direct plasma interaction with living tissue," New Journal of Physics, vol. 11, p. $115020,2009$.

[9] A. Fridman, Plasma chemistry: Cambridge Univ Press. Cambridge, U.K., 2008.

[10] H. Sies, "Strategies of antioxidant defense," European Journal of Biochemistry, vol. 215, pp. 213-219, 1993.

[11] W. A. Pryor, "Oxy-radicals and related species: their formation, lifetimes, and reactions," Annual Review of Physiology, vol. 48, pp. 657-667, 1986.

[12] H. Sies, W. Stahl, and A. R. Sundquist, "Antioxidant functions of vitamins," Annals of the New York Academy of Sciences, vol. 669, pp. 7-20, 1992.

[13] L. Forni, D. Bahnemann, and E. J. Hart, "Mechanism of the hydroxide ion-initiated decomposition of ozone in aqueous solution," The Journal of Physical Chemistry, vol. 86, pp. 255-259, 1982.

[14] J. Staehelin and J. Hoigne, "Decomposition of ozone in water: rate of initiation by hydroxide ions and hydrogen peroxide," Environmental Science \& Technology, vol. 16, pp. 676-681, 1982.

[15] R. Zika and E. Saltzman, "Interaction of ozone and hydrogen peroxide in water: implications for analysis of H2O2 in air," Geophysical Research Letters, vol. 9, pp. 231234, 1982.

[16] S. J. Masten and S. H. R. Davies, "The use of ozonization to degrade organic contaminants in wastewaters," Environmental Science \& Technology, vol. 28, pp. 180$185,1994$. 
[17] A. A. Joshi, B. Locke, P. Arce, and W. Finney, "Formation of hydroxyl radicals, hydrogen peroxide and aqueous electrons by pulsed streamer corona discharge in aqueous solution," Journal of hazardous materials, vol. 41, pp. 3-30, 1995.

[18] C. Yamabe, F. Takeshita, T. Miichi, N. Hayashi, and S. Ihara, "Water treatment using discharge on the surface of a bubble in water," Plasma Processes and Polymers, vol. 2, pp. 246-251, 2005.

[19] B. R. Locke and K. Y. Shih, "Review of the methods to form hydrogen peroxide in electrical discharge plasma with liquid water," Plasma Sources Science and Technology, vol. 20, p. 034006, 2011.

[20] S. Medodovic and B. Locke, "Primary chemical reactions in pulsed electrical discharge channels in water," Journal of Physics D: Applied Physics, vol. 42, p. 049801, 2009.

[21] H.-S. Kim, K. C. Wright, I.-W. Whang, D.-H. Lee, A. Rabinovich, A. Fridman, et al., "Concentration of hydrogen peroxide generated by gliding arc discharge and inactivation of E. coli in water," International Communications in Heat and Mass Transfer, 2012.

[22] A. Fridman, S. Nester, L. A. Kennedy, A. Saveliev, and O. Mutaf-Yardimci, "Gliding arc gas discharge," Progress in Energy and Combustion Science, vol. 25, pp. 211-231, 1998.

[23] A. Fridman, A. Chirokov, and A. Gutsol, "Non-thermal atmospheric pressure discharges," Journal of Physics D: Applied Physics, vol. 38, p. R1, 2005.

[24] K. P. Arjunan, G. Friedman, A. Fridman, and A. M. Clyne, "Non-thermal dielectric barrier discharge plasma induces angiogenesis through reactive oxygen species," Journal of The Royal Society Interface, vol. 9, pp. 147-157, 2012. 
[25] C. S. Kalra, Y. I. Cho, A. Gutsol, A. Fridman, and T. S. Rufael, "Gliding arc in tornado using a reverse vortex flow," Review of Scientific Instruments, vol. 76, p. 025110, 2005.

[26] C. A. Lesueur H, Chappelle J., "Electrically assisted partial oxidation of methane," Int J Hydrogen Energy, vol. 19, pp. 139-145, 1994.

[27] A. Gutsol, J. Larjo, and R. Hernberg, "Comparative calorimetric study of ICP generator with forward-vortex and reverse-vortex stabilization," Plasma Chemistry and Plasma Processing, vol. 22, pp. 351-369, 2002.

[28] A. Essiptchouk, L. Charakhovski, H. Maciel, C. Otani, and E. Barros, "Thermal and power characteristics of plasma torch with reverse vortex," Journal of Physics D: Applied Physics, vol. 42, p. 175205, 2009.

[29] R. Burlica, R. Grim, K. Y. Shih, D. Balkwill, and B. Locke, "Bacteria inactivation using low power pulsed gliding arc discharges with water spray," Plasma Processes and Polymers, vol. 7, pp. 640-649, 2010.

[30] H.-S. Kim, K. C. Wright, I.-H. Hwang, D.-H. Lee, A. Rabinovich, A. A. Fridman, et al., "Effects of $\mathrm{H} 2 \mathrm{O} 2$ and Low pH Produced by Gliding Arc Discharge on the Inactivation of Escherichia Coli in Water," Plasma Medicine, vol. 1, 2011.

[31] W. H. Glaze, J.-W. Kang, and D. H. Chapin, "The chemistry of water treatment processes involving ozone, hydrogen peroxide and ultraviolet radiation," The Journal of the International Ozone Association vol. 9, pp. 335-352, 1987.

[32] C. W. Chen, H. M. Lee, and M. B. Chang, "Inactivation of aquatic microorganisms by low-frequency AC discharges," Plasma Science, IEEE Transactions, vol. 36, pp. 215219, 2008. 
[33] H. S. Kim, Y. I. Cho, I. H. Hwang, D. H. Lee, D. J. Cho, A. Rabinovich, et al., "Use of plasma gliding arc discharges on the inactivation of E. Coli in water," Separation and Purification Technology, vol. 120, pp. 423-428, 2013.

[34] A. Bruhn, L. Liberona, C. Lisboa, and G. Borzone, "Limitations of the technique to determine hydrogen peroxide levels in exhaled breath condensate from patients with adult respiratory distress syndrome," Archivos de Bronconeumología ((English Edition)), vol. 41, pp. 542-546, 2005.

[35] P. K. Sharma, M. J. Gibcus, H. C. Van Der Mei, and H. J. Busscher, "Influence of fluid shear and microbubbles on bacterial detachment from a surface," Applied and Environmental Microbiology, vol. 71, pp. 3668-3673, 2005.

[36] H. Papen and R. Von Berg, "A most probable number method (MPN) for the estimation of cell numbers of heterotrophic nitrifying bacteria in soil," Plant and Soil, vol. 199, pp. 123-130, 1998.

[37] Y. Kott, "Estimation of low numbers of Escherichia coli bacteriophage by use of the most probable number method," Applied Microbiology, vol. 14, pp. 141-144, 1966.

[38] D. J. Reasoner, "Heterotrophic plate count methodology in the United States," International Journal of Food Microbiology, vol. 92, pp. 307-315, 2004.

[39] M. W. LeChevallier and G. A. McFETERS, "Interactions between heterotrophic plate count bacteria and coliform organisms," Applied and Environmental Microbiology, vol. 49, pp. 1338-1341, 1985.

[40] R. Burlica, K.-Y. Shih, and B. Locke, "Formation of H2 and H2O2 in a water-spray gliding arc nonthermal plasma reactor," Industrial \& Engineering Chemistry Research, vol. 49, pp. 6342-6349, 2010. 
[41] J. Manion, R. Huie, R. Levin, D. Burgess Jr, V. Orkin, W. Tsang, et al., "NIST chemical kinetics database, NIST standard reference database 17, version 7.0 (web version), release 1.4. 3, data version 2008.12, National Institute of Standards and Technology, Gaithersburg, Maryland, 20899-8320," Web address: http://kinetics. nist. gov, 2008.

[42] G. Sathiamoorthy, S. Kalyana, W. Finney, R. Clark, and B. Locke, "KINETICS, CATALYSIS, AND REACTION ENGINEERING-Chemical Reaction Kinetics and Reactor Modeling of NOx Removal in a Pulsed Streamer Corona Discharge Reactor," Industrial and Engineering Chemistry Research, vol. 38, pp. 1844-1855, 1999.

[43] R. Burlica, M. J. Kirkpatrick, and B. R. Locke, "Formation of reactive species in gliding arc discharges with liquid water," Journal of Electrostatics, vol. 64, pp. 35-43, 2006.

[44] I. Campbell and B. Thrush, "Behaviour of carbon dioxide and nitrous oxide in active nitrogen," Transactions of the Faraday Society, vol. 62, pp. 3366-3374, 1966.

[45] R. Atkinson, D. Baulch, R. Cox, J. Crowley, R. Hampson, R. Hynes, et al., "Evaluated kinetic and photochemical data for atmospheric chemistry: Volume I-gas phase reactions of Ox, HOx, NOx and SOx species," Atmospheric chemistry and physics, vol. 4, pp. 1461-1738, 2004.

[46] C. F. Williams, S. K. Pogrebnya, and D. C. Clary, "Quantum study on the branching ratio of the reaction $\mathrm{NO} 2+\mathrm{OH}, "$ The Journal of chemical physics, vol. 126, p. 154321, 2007.

[47] B. Benstaali, P. Boubert, B. Cheron, A. Addou, and J. Brisset, "Density and rotational temperature measurements of the $\mathrm{OH}$ and $\mathrm{NO}$ radicals produced by a gliding arc in humid air," Plasma chemistry and plasma processing, vol. 22, pp. 553-571, 2002. 
[48] B. R. Locke and S. M. Thagard, "Analysis of chemical reactions in gliding-arc reactors with water spray into flowing oxygen," Plasma Science, IEEE Transactions on, vol. 37, pp. 494-501, 2009.

[49] B. Benstaali, D. Moussa, A. Addou, and J. Brisset, "Plasma treatment of aqueous solutes: some chemical properties of a gliding arc in humid air," EPJ APPLIED PHYSICS, vol. 4, pp. 171-180, 1998.

[50] M. Laroussi, "Nonthermal decontamination of biological media by atmospheric-pressure plasmas: Review, analysis, and prospects," Plasma Science, IEEE Transactions, vol. 30, pp. 1409-1415, 2002.

[51] M. Yamamoto, M. Nishioka, and M. Sadakata, "Sterilization by H2O2 droplets under corona discharge," Journal of Electrostatics, vol. 55, pp. 173-187, 2002.

[52] A. Abou-Ghazala, S. Katsuki, K. H. Schoenbach, F. Dobbs, and K. Moreira, "Bacterial decontamination of water by means of pulsed-corona discharges," Plasma Science, IEEE Transactions, vol. 30, pp. 1449-1453, 2002.

[53] P. Lukes, M. Clupek, V. Babicky, and T. Vykouk, "Bacterial inactivation by pulsed corona discharge in water," in Pulsed Power Conference, 2007 16th IEEE International, 2007, pp. 320-323.

[54] M. Dors, E. Metel, J. Mizeraczyk, and E. Marotta, "Pulsed corona discharge in water for coli bacteria inactivation," in Dielectric Liquids, 2008. ICDL 2008. IEEE International Conference, 2008, pp. 1-3.

[55] Y. C. Hong, H. J. Park, B. J. Lee, W.-S. Kang, and H. S. Uhm, "Plasma formation using a capillary discharge in water and its application to the sterilization of E. coli," Physics of Plasmas, vol. 17, p. 053502, 2010. 
[56] Y.-J. Kim, Y.-C. Hong, S.-J. Lee, and B.-J. Lee, "Plasma formation using a capillary discharge in water for biotechnological applications," Journal of the Korean Physical Society, vol. 60, pp. 921-924, 2012. 


\section{List of Figures}

Fig. 1. Experimental setup for the present plasma-water-treatment system using gliding arc discharge $; \mathrm{HV}=$ high-voltage power supply, $\mathrm{MBG}=$ microbubble generator, $\mathrm{PG}=$ pressure regulator.

Fig. 2. Circuit diagram of a power supply connecting with gliding arc discharge generator; $1=$ Voltage rectifier with diode bridge, $2=$ Capacitors, $3=$ Transistor to control primary coil, $4=$ Primary coil, 5 = Secondary H.V. coil, $6=$ Electromagnetic interference filter, $\mathrm{Ch}-1=$ Voltage measurement with HV probe (x 1000), Ch-2 = Current measurement with magnetic core probe $(\mathrm{x} 10 \mathrm{~A} / \mathrm{V})$

Fig. 3. Profiles of voltage and current used to generate the gliding arc discharge in the present study. $(\mathrm{U}=$ voltage, $\mathrm{I}=$ current, $\mathrm{T}=30 \mu \mathrm{s}, \mathrm{f}=33.3 \mathrm{kHz})$

Fig. 4. Variations of $\mathrm{H}_{2} \mathrm{O}_{2}$ concentrations in water at various air flow rates and water injection flow rates through gliding arc discharge generator.

Fig. 5. Control test: Results of E. coli inactivation experiment with sham plasma treatment with water injection flow rate of $120 \mathrm{~mL} / \mathrm{min}$ and air flow rate of $3.8 \mathrm{scfm}$.

Fig. 6A. Plasma treatment for 10 min: Results of E. coli inactivation experiments and $\mathrm{pH}$ variations with an initial water volume of $20 \mathrm{~L}$ at reservoir with $1.78 \mathrm{~kJ} / \mathrm{L}$ of plasma energy consumption

Fig. 6B. Plasma treatment for 13 min: Results of E. coli inactivation experiments and $\mathrm{pH}$ variations with an initial water volume of $20 \mathrm{~L}$ at reservoir with $2.31 \mathrm{~kJ} / \mathrm{L}$ of plasma energy consumption. 
Fig. 6C. Plasma treatment for 16 min: Results of E. coli inactivation experiments and $\mathrm{pH}$ variations with an initial water volume of $20 \mathrm{~L}$ at reservoir with $2.85 \mathrm{~kJ} / \mathrm{L}$ of plasma energy consumption.

Fig. 6D. Plasma treatment for $25 \mathrm{~min}$ : Results of E. coli inactivation experiments and $\mathrm{pH}$ variations with an initial water volume of $20 \mathrm{~L}$ at reservoir with $4.56 \mathrm{~kJ} / \mathrm{L}$ of plasma energy consumption.

Fig. 7. Results of E. coli inactivation experiments with various treatment times (plasma energy) in an initial water volume of $20 \mathrm{~L}$ at reservoir.

Fig. 8. Results of $\mathrm{pH}$ changes experiments with various treatment times (plasma energy) in an initial water volume of $20 \mathrm{~L}$ at reservoir. 
Table 1. Chemical reactions and rate functions $[9,20,41,44,45,46]$

\begin{tabular}{|c|l|c|c|l|}
\hline $\begin{array}{c}\text { Reaction } \\
\text { Number }\end{array}$ & \multicolumn{1}{|c|}{ Reactions } & $\begin{array}{c}\text { Temp. } \\
\text { range }(\mathrm{K})\end{array}$ & $\begin{array}{c}\text { Reaction } \\
\text { Order }\end{array}$ & \multicolumn{1}{|c|}{ Rate constant } \\
\hline $1-1$ & $\mathrm{e}+\mathrm{H}_{2} \mathrm{O} \rightarrow \mathrm{H}+\mathrm{OH}+\mathrm{e}^{-}$ & $2,000-6,000$ & 2 & $5.8 \times 10^{-9} \mathrm{exp}(-440 \mathrm{~kJ} / \mathrm{RT})$ \\
\hline $1-2$ & $\mathrm{e}+\mathrm{H}_{2} \mathrm{O} \rightarrow \mathrm{H}^{-}+\mathrm{OH}$ & $2,000-6,000$ & 2 & $5.8 \times 10^{-9} \mathrm{exp}(-440 \mathrm{~kJ} / \mathrm{RT})$ \\
\hline $1-3$ & $\mathrm{M}^{+}+\mathrm{H}_{2} \mathrm{O} \rightarrow \mathrm{H}_{2} \mathrm{O}^{+}+\mathrm{M}$ & $\approx 300$ & 2 & $2.2 \times 10^{-9}$ \\
\hline $1-4$ & $\mathrm{H}_{2} \mathrm{O}^{+}+\mathrm{H}_{2} \mathrm{O} \rightarrow \mathrm{H}_{3} \mathrm{O}^{+}+\mathrm{OH}$ & $\approx 350$ & 2 & $0.5 \times 10^{-9}$ \\
\hline $1-5$ & $\mathrm{OH}+\mathrm{OH}+\mathrm{M} \rightarrow \mathrm{H}_{2} \mathrm{O}_{2}+\mathrm{M}$ & $200-1,500$ & 2 & $1.51 \times 10^{-11}(\mathrm{~T} / 298)^{-0.37}$ \\
\hline $2-1$ & $\mathrm{~N}_{2}+\mathrm{e} \rightarrow 2 \mathrm{~N}+\mathrm{e}^{-}$ & $\approx 5,000$ & 2 & $2 \times 10^{-11}$ \\
\hline $2-2$ & $\mathrm{O}_{2}+\mathrm{e} \rightarrow 2 \mathrm{O}+\mathrm{e}^{-}$ & $\approx 20,000$ & 2 & $10^{-10}-10^{-9}$ \\
\hline $2-3$ & $\mathrm{~N}+\mathrm{O}+\mathrm{M} \rightarrow \mathrm{NO}^{-9} \mathrm{M}$ & $196-327$ & 3 & $7.31 \times 10^{-33} \mathrm{exp}(1.12 \mathrm{~kJ} / \mathrm{RT})$ \\
\hline $2-4$ & $\mathrm{NO}^{-} \mathrm{O}+\mathrm{M} \rightarrow \mathrm{NO}^{2}+\mathrm{M}$ & 298 & 3 & $1.0 \times 10^{-31}$ \\
\hline $2-5$ & $\mathrm{NO}_{2}+\mathrm{OH}^{2} \mathrm{HNO}_{3}$ & $200-400$ & 2 & $4.0 \times 10^{-11}$ \\
\hline
\end{tabular}




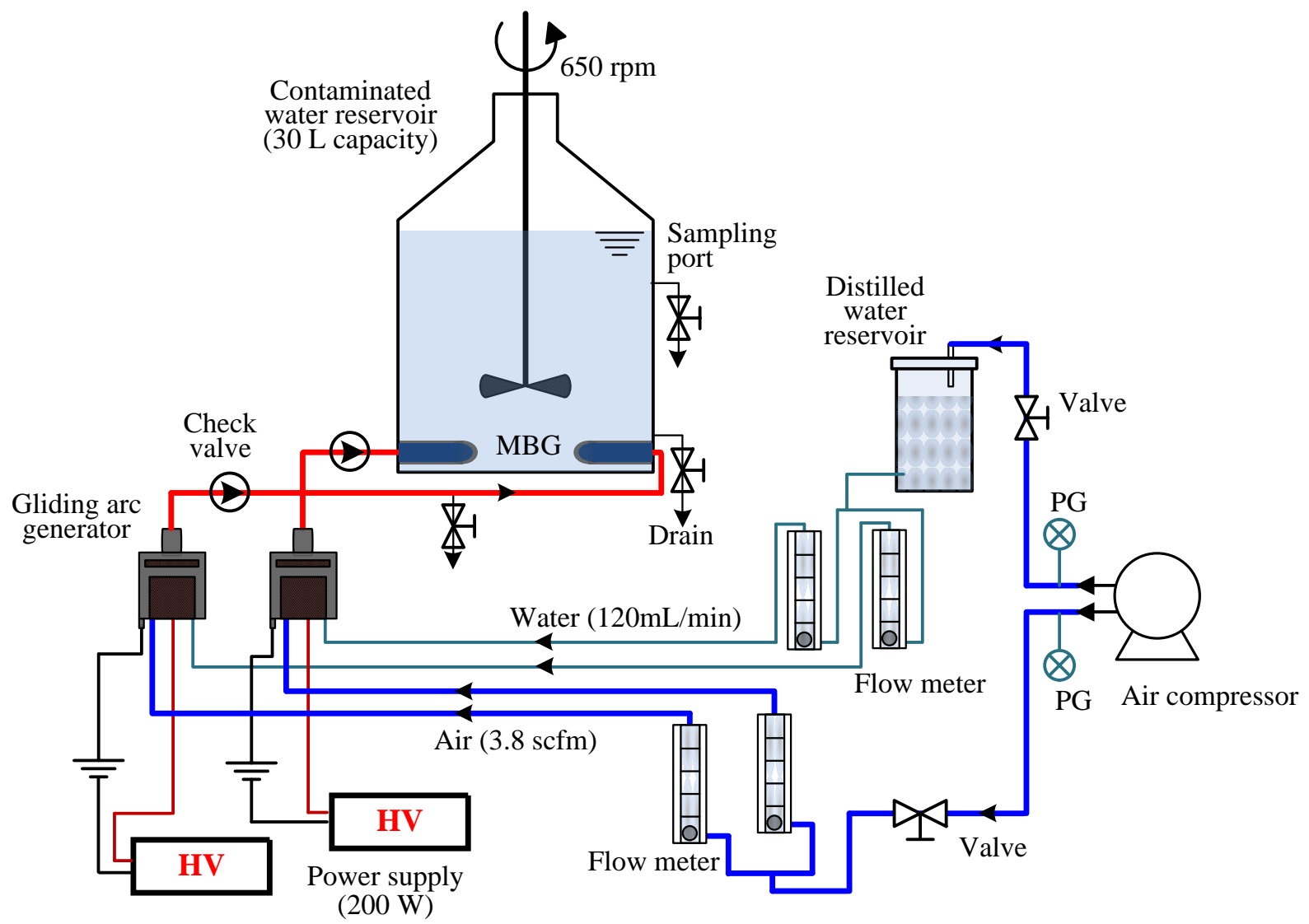

Fig. 1. 


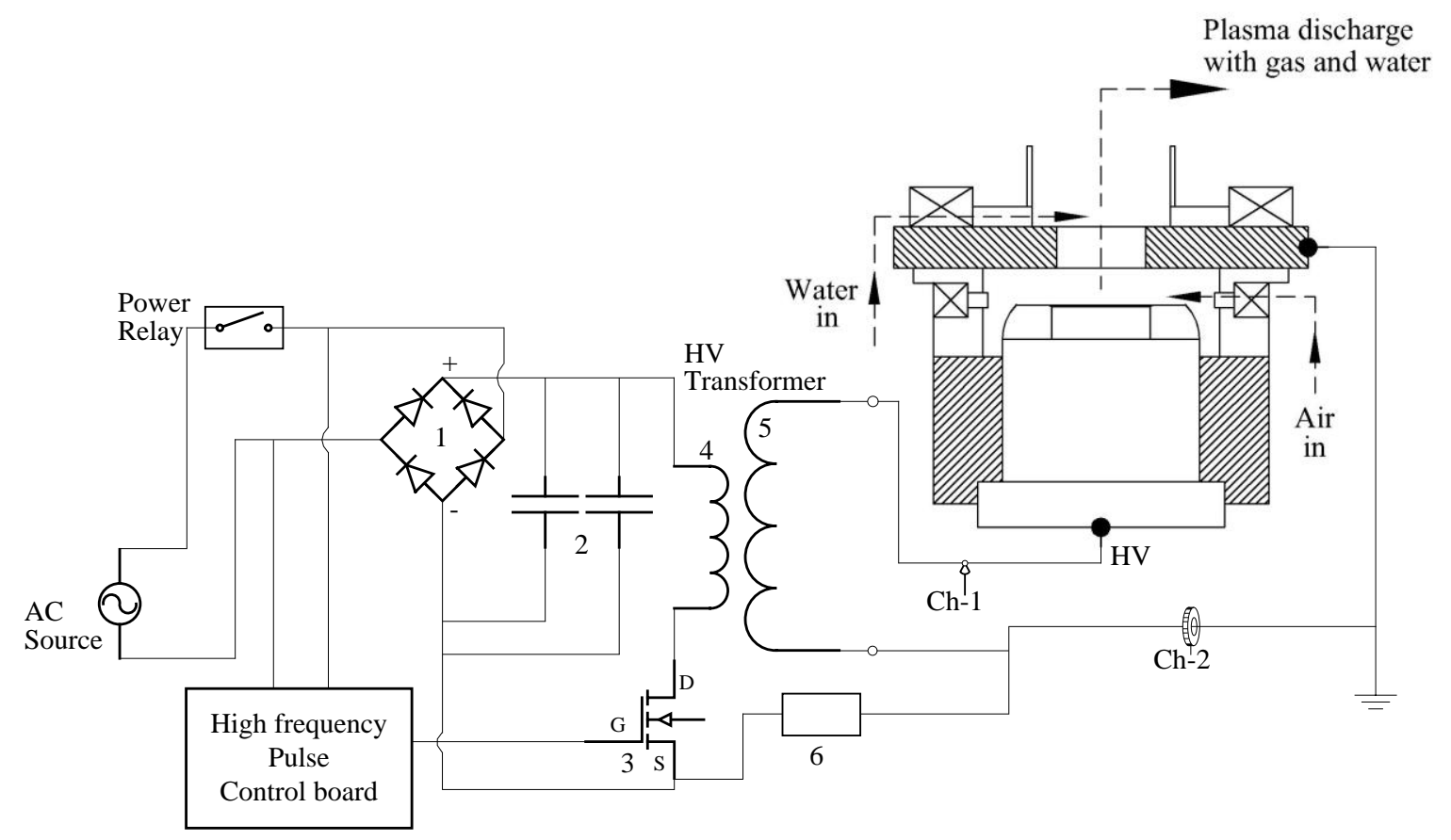

Fig. 2. 


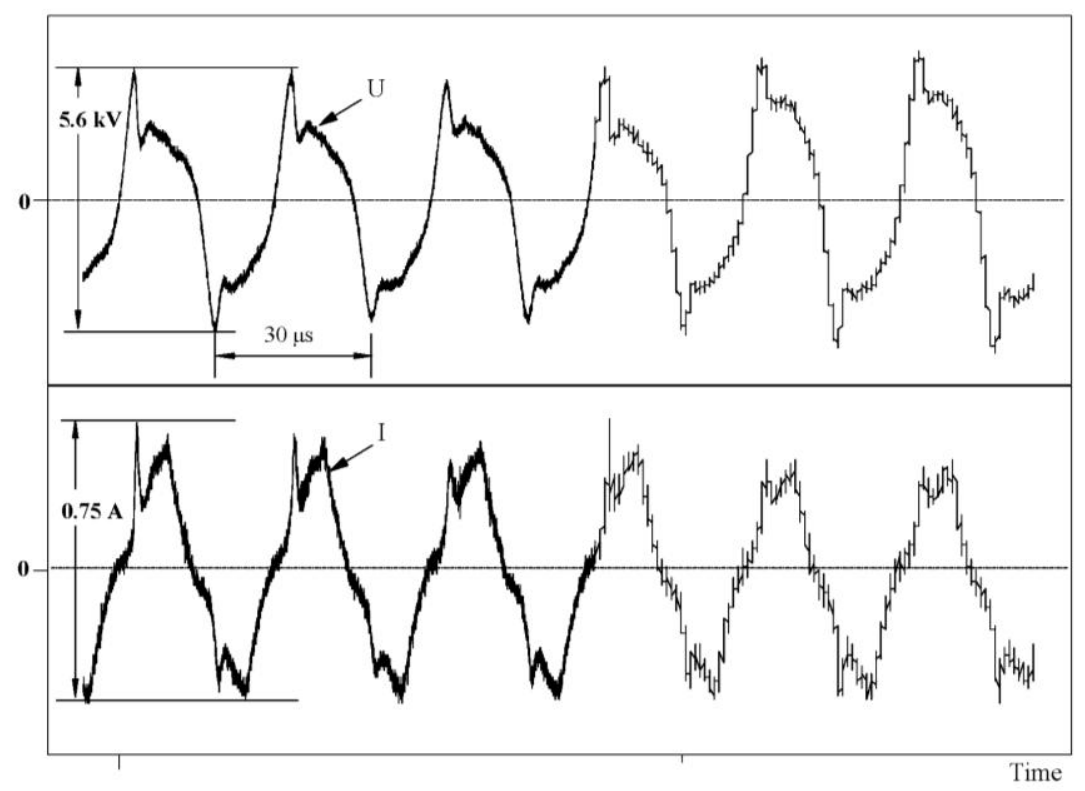

Fig. 3. 


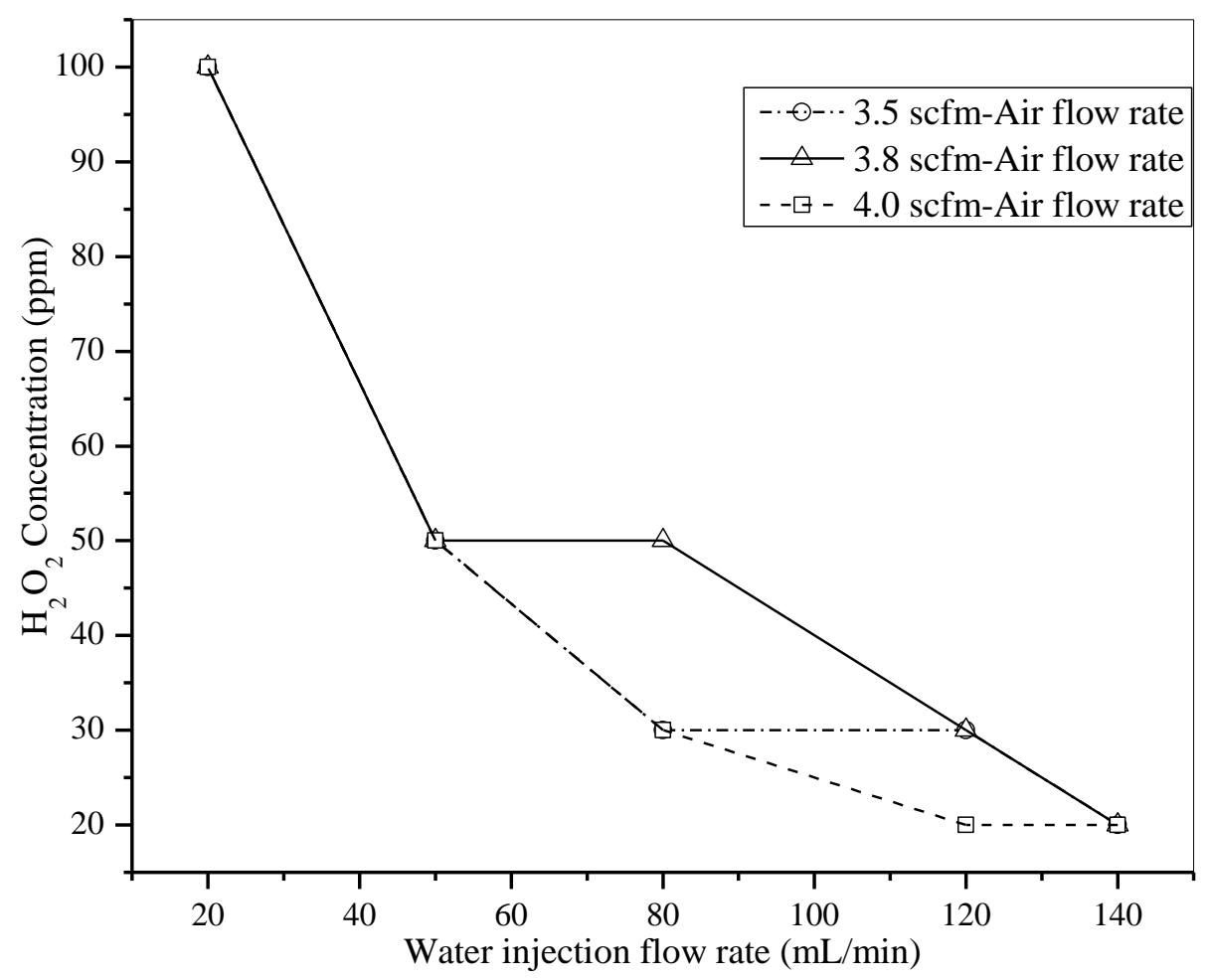

Fig. 4. 


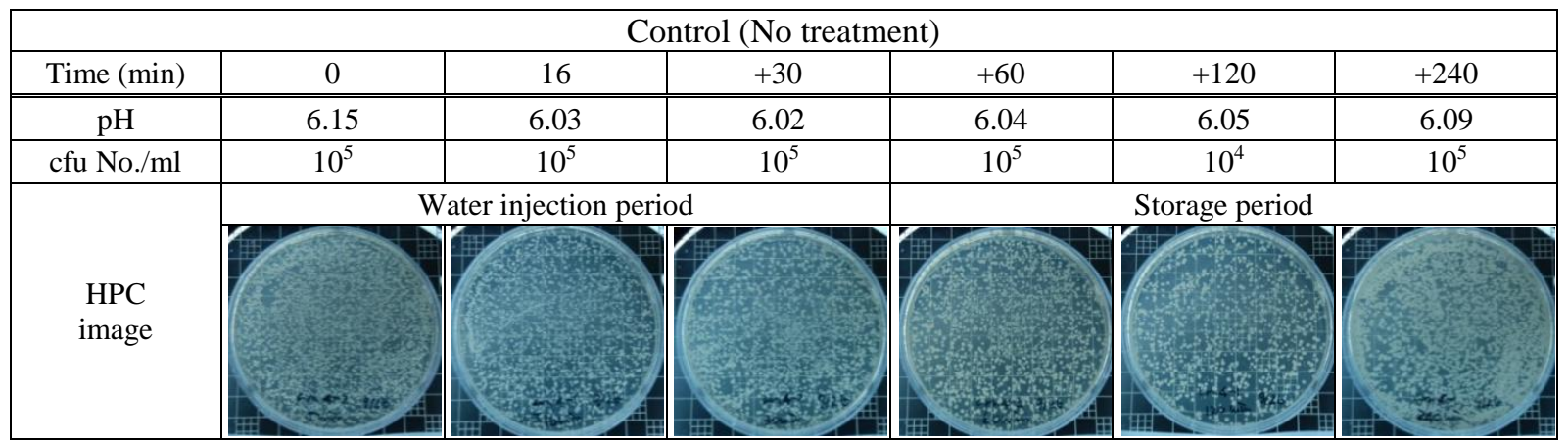

Fig. 5. 


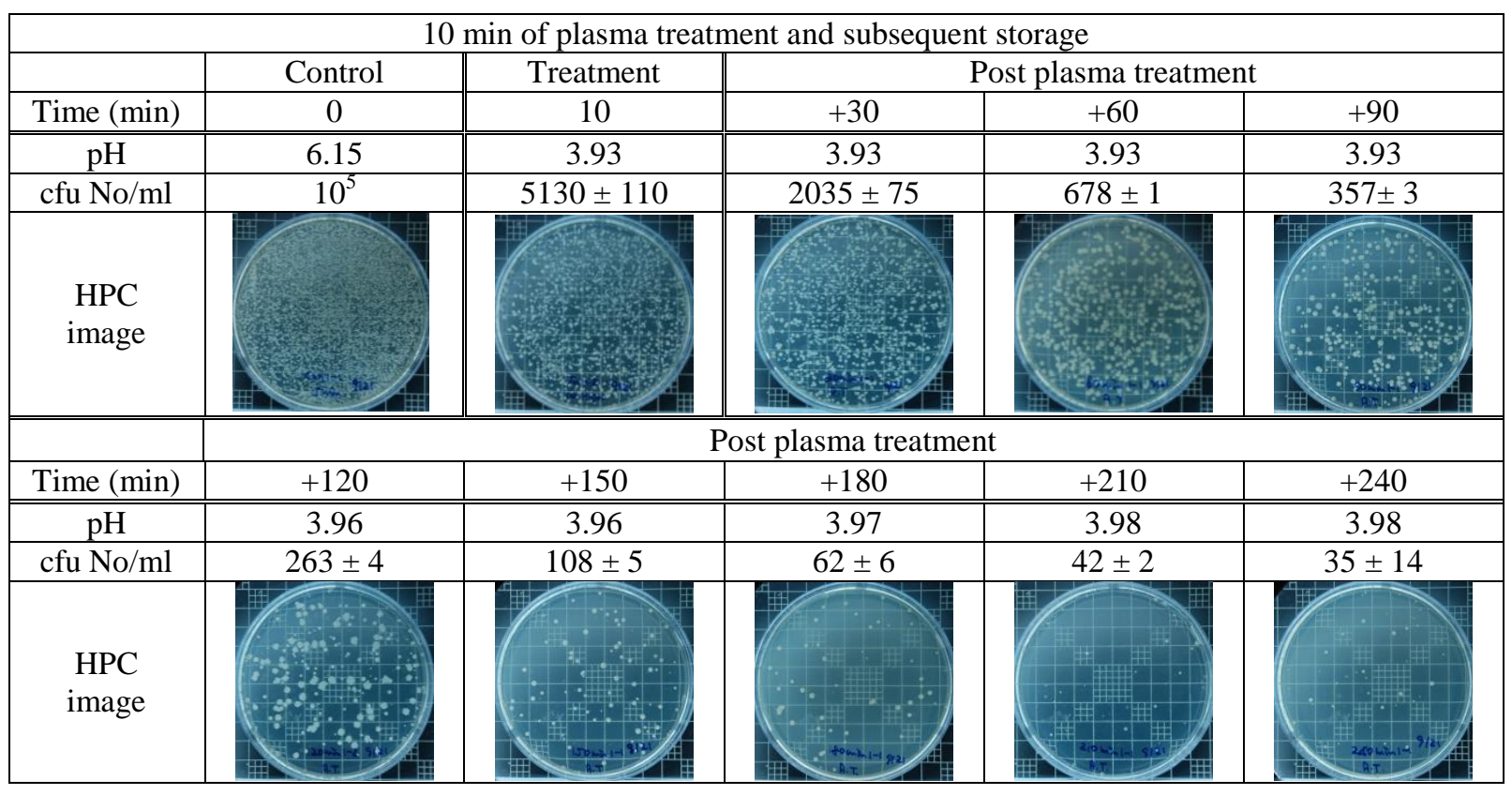

Fig. 6A. 


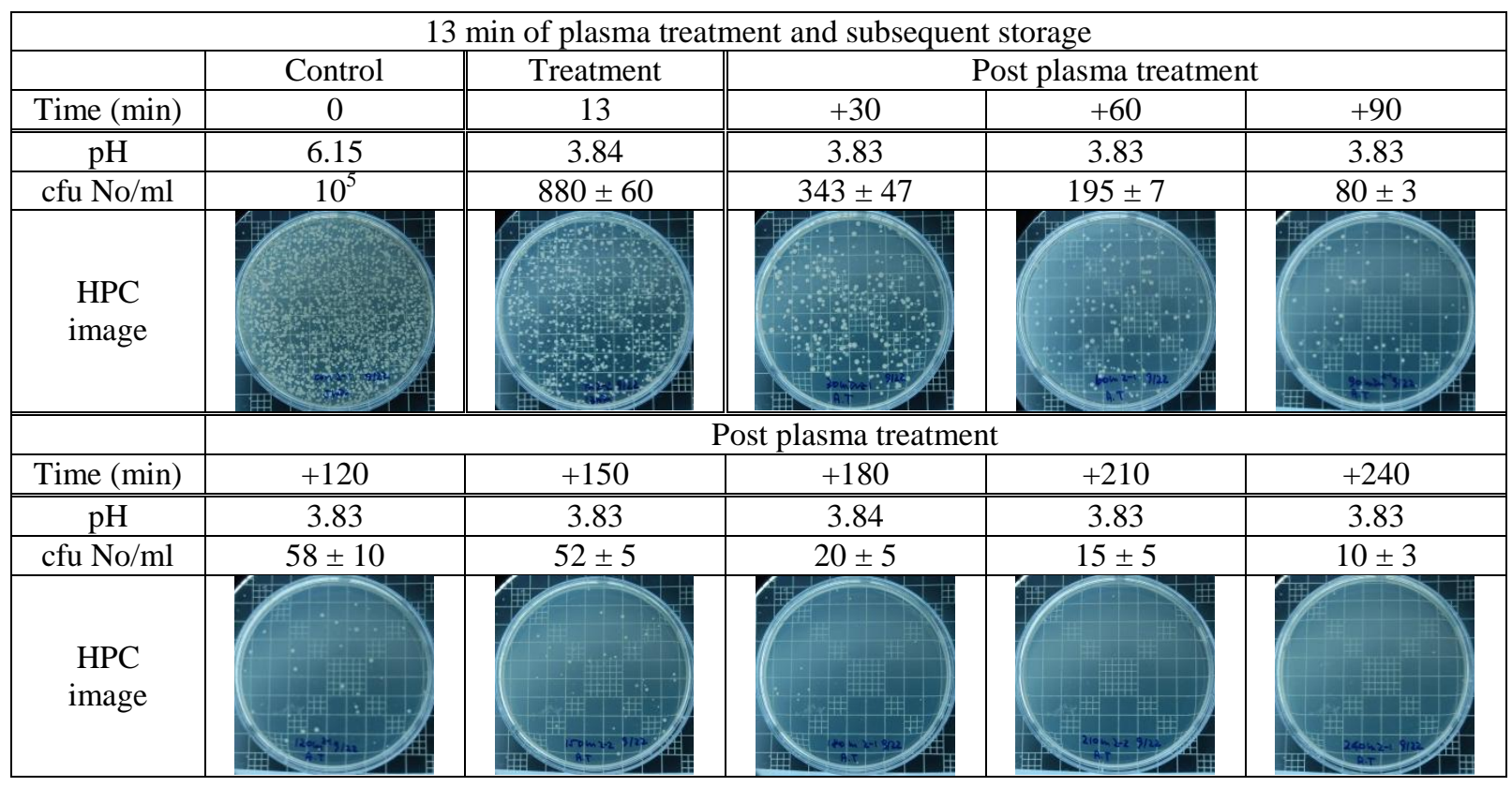

Fig. 6B. 


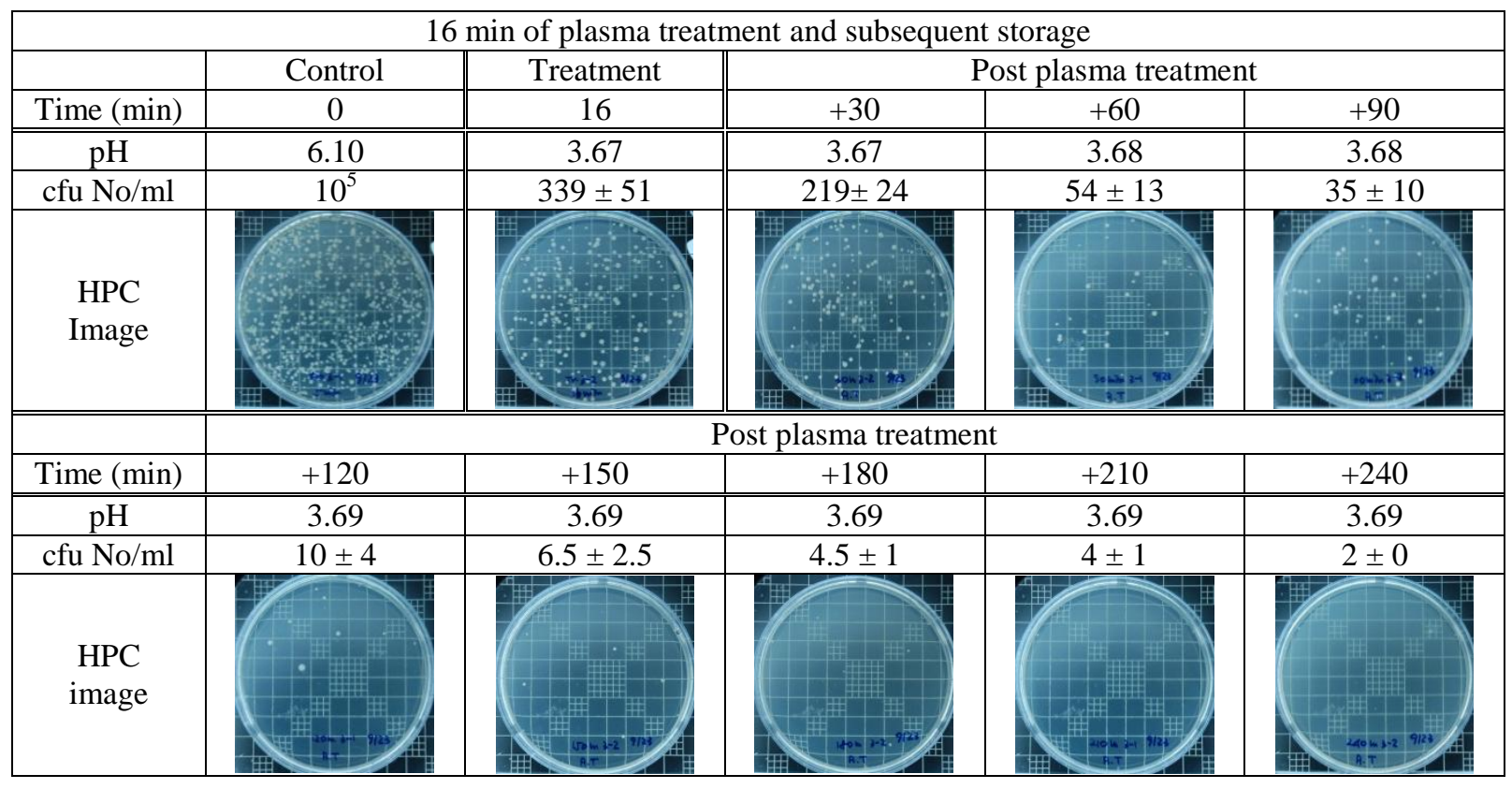

Fig. 6C. 


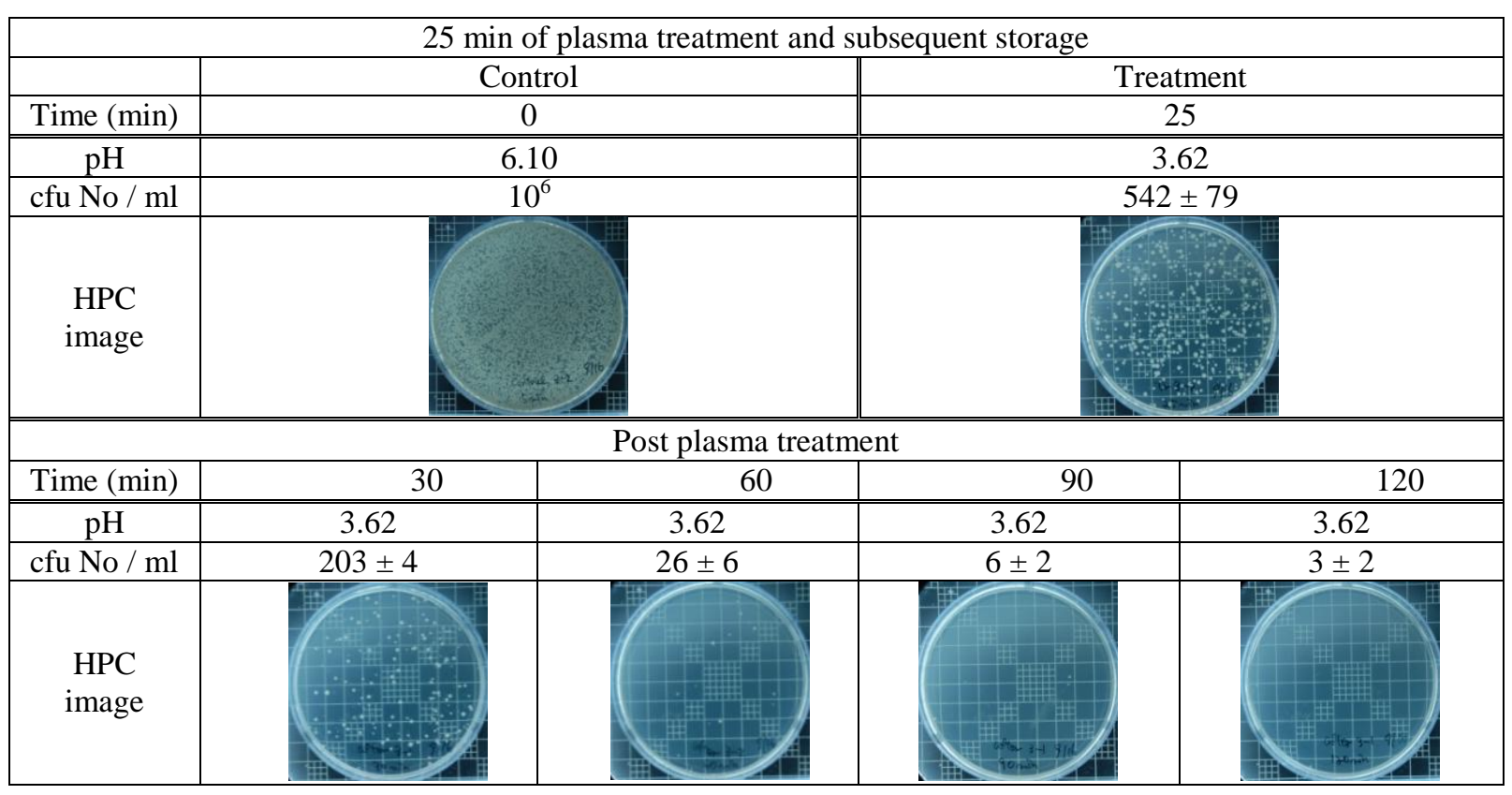

Fig. 6D. 


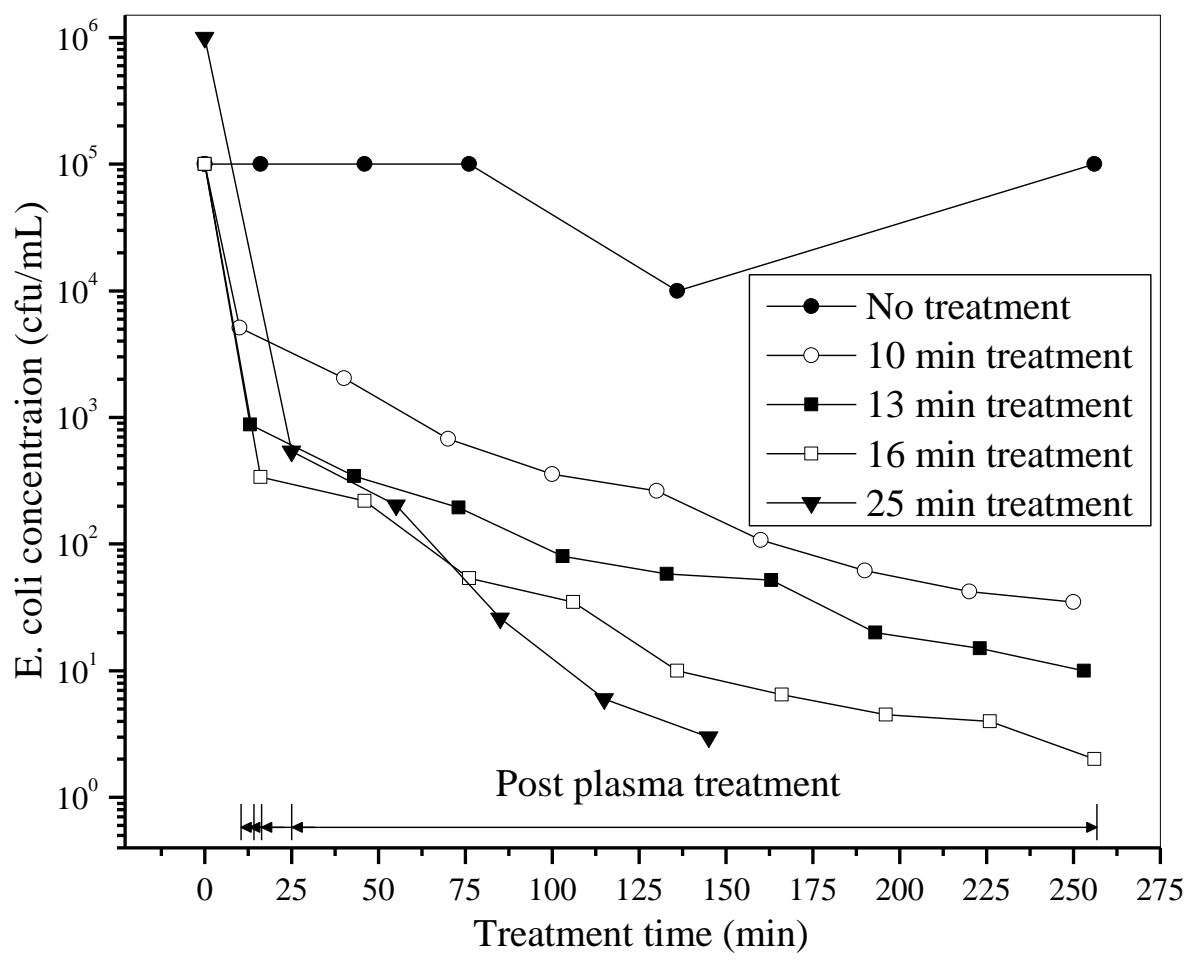

Fig. 7. 


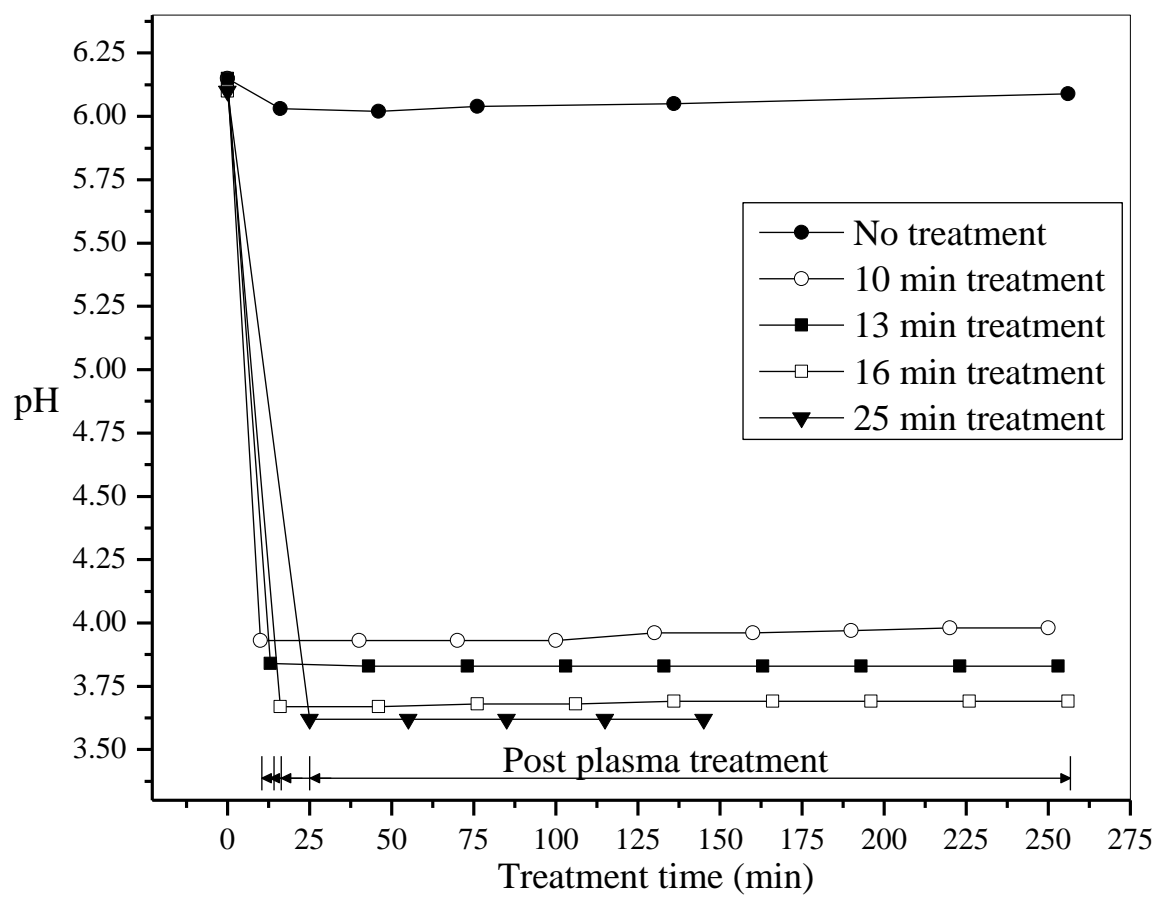

Fig. 8. 